\section{Department puts money on wind}

THE British government, which in 1975 spent $£ 0.5$ million on renewable energy research, has since taken a wait-and-see attitude towards unconventional sources of energy. Now, backed by reports from the Advisory Council on Research and Development for Fuel and Power (ACORD), it seems to be coming off the fence. Technologies that the Department of Energy (DOE) calls "winners" - wind, solar, biofuels and geothermal hot dry rocks - will be financed for further research and development, but "less promising" options, notably the $£ 17$ million research programme into wave power, will be halted until further notice.

Mr David Hunt, the DOE minister responsible for renewables, earlier this month defended both the amount of government spending and its choices. This year, $£ 14$ million has been earmarked for renewables research which, $\mathrm{Mr}$ Hunt pointed out, should be increased to $£ 20$ million from European and other sources. He claims that these figures demonstrate a commitment to renewables as part of the energy grid.

Questioned whether the increase of cash spending from $£ 16$ million in the five years $1975-80$ to $£ 68$ million in $1980-85$ may mask a decrease in commitment, $\mathrm{Mr}$ Hunt said that renewables technology "stands up for itself" and should not be judged in terms of the spending on other energy sources. In any case, he claims, the government's programme is "the most positive commitment by any [British] government" to renewable energy sources.

Backing the winners - and wind is "no doubt the most promising" - will mean that more money is channelled into the technologies that ACORD and DOE have labelled as "economically attractive" or "promising but uncertain", and which may make a significant contribution by 2025. Technologies judged less viable, such as converting wave energy into a more usable form, will not be funded but DOE will monitor developments abroad and be ready to change tack. Mr Hunt urged members of the renewable resources community to look beyond their hobbyhorses and to accept the commercial common sense of backing such sources as wind, in which Britain enjoys "world-beating" technology. Only then would these technologies be got "out of the research stations, off the drawing boards and into our daily lives"

ACORD's enthusiasm for wind reflects world optimism, especially in the United States, where wind turbine farms already generate a significant amount of energy. DOE plans to concentrate on large-scale machines, both horizontal and vertical axis, and emphasizes the export possibilities as well as the generation of energy for remote areas of Britain. Research ex- penditures in 1984-85 of approximately $£ 4.5$ million were roughly double those of the previous year; $£ 6$ million is budgeted for 1985-86.

The significant British milestones are at Burgar Hill in Orkney and at Carmarthen Bay. At Orkney a $250 \mathrm{~kW}$ horizontal axis machine, built as a prototype, has operated for 2,303 hours and generated 212,533 al axis turbine has been approved for the same site. Work at Carmarthen Bay has centred on building a multi-megawatt vertical axis turbine. ACORD estimates for 2025 suggest a 1.6 million tonnes of coal equivalent (Mtce) a year contribution from such onshore sites. Offshore development is still at a theoretical stage, but plans for both national and international projects are afoot.

DOE is also backing passive solar energy, the direct solar heating of buildings, a potential winner that "makes good economic sense". The private sector, according to Hunt, will be encouraged to design buildings that "make the most of sun shine", thereby cutting heating and lighting costs by as much as 30 per cent. ACORD describes passive solar design as a technology that "has come to fruition and is ready to enter the market"

Unlike wind energy projects, in which many technical obstacles impede largescale use, ACORD finds the impediment to solar energy to be customer diffidence. Potential customers must accept that a solar design does not entail putting up with an unattractive living arrangement. Passive solar's estimated contribution by 2025 is 2 Mtce per year for the domestic sector.

By ACORD's definition, biofuel is nonfossil combustible material, such as dry biomass (straw, wood), wet wastes (animal slurry, food industry wastes) and energy crops (trees or plants grown specifically for energy). ACORD sees organic wastes as the main biofuels in the next 20-30 years. Research is now to be concentrated on the best conversion technologies - direct combustion, thermal processing, anaerobic digestion - for the various forms of waste. ACORD predicts a 1.6 and $8 \mathrm{Mtce}$ a year contribution from wet and dry wastes respectively.

DOE also plans to continue support for geothermal hot dry rocks because of promising experimental results, even though actual output is uncertain. Research is now centred at Rosemanowes, Cornwall, in a project run by the Camborne School of Mines. The idea is to cut holes to depths of $2,000-6,000$ metres, artificially fracture the rock and heat water by circulating it through these reservoirs. The project is now waiting for results from a third hole that was recently dug; if these are positive, more and deeper holes will be drilled. $\mathrm{kWh}$; now a $60 \mathrm{~m}$ diameter $3 \mathrm{MW}$ horizont-
Achieving technical feasibility, however, is not the final hurdle before a renewable energy project is built. These projects often have high start-up costs that are less easily dissociated from the project than are the clean-up costs of conventional energy sources. According to Mr Hunt, allowances will be made for alternative energy sources in Britain. Elizabeth Collins

\section{Wind power West Germany backs out}

\section{Hamburg}

GROWIAN, (for Grosse Windenergie Anlage) the largest wind-driven power plant in the world, is to be dismantled. Situated on the estuary of the Elbe, it could, at least on windy days (around 300 a year), produce $3 \mathrm{MW}$ of electrical power.

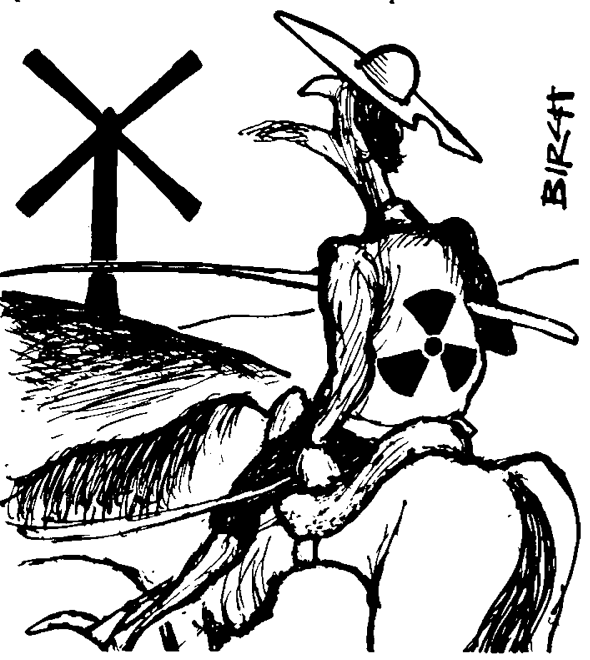

Developed during the oil crisis, the windmill was constructed in the early 1980 s at a total cost of DM90 million (£22.5 million). Now cracks have appeared in the rotor framework which would require a further DM10 million to repair. Dr Heinz Riesenhuber (CDU), Minister for Research and Technology in the West German government, has decided instead to close the gigantic propeller down next year and to have it dismantled later. The call for the development of alternative sources of energy has become less strident now that the costs of conventional sources have stabilized, which is why the wind energy programme begun by the Social Democrat/Liberal coalition faces its end.

So far this programme has cost DM200 million, a small sum compared with the DM1,600 million invested in nuclear energy, mainly in the fast-breeder reactor plant at Kalkar. The GROWIAN project was at the outset criticized for its enormous size, and for the expected difficulty of operating such a large machine. Its cancellation is seen as a success for the nuclear lobby, which has always maintained that alternative sources of energy have no future in West Germany. Jürgen Neffe 